\title{
The Socialization Headmaster To Learning Covid-19 At Madrasah Darussalam Foundation Gunung Tua
}

\author{
Muhammad Fuad Zaini' ${ }^{1}$ Indah Melia Putri Siregar ${ }^{2}$ \\ 1 Stai Jam'iyah Mahmudiyah \\ 2 State Islamic University Of North Sumatra \\ Corresponding Author muhammad_fuadzaini@staijm.ac.id
}

\begin{tabular}{cl}
\hline & \multicolumn{1}{c}{ ABSTRACT } \\
\cline { 2 - 3 } ARTICLE INFO & $\begin{array}{l}\text { The impact that occurs on learning in every school is greatly affected } \\
\text { by the Covid-19 pandemic. This study reveals how the learning } \\
\text { situation during the pandemic at the Madrasah Darussalam }\end{array}$ \\
$\begin{array}{c}\text { Received } \\
\text { 05 Agustus 2021 } \\
\text { Revised }\end{array}$ & $\begin{array}{l}\text { Foundation, Gunung Tua Paluta. In this study, the method used is a } \\
\text { qualitative research method with this method intended to find more } \\
\text { factual data in the field for further analysis. As for the results of the } \\
\text { study, the difficulties of teachers in conducting online learning in }\end{array}$ \\
18 Agustus 2021 & $\begin{array}{l}\text { madrasas, difficulties in understanding by students, especially } \\
\text { arithmetic subjects. student achievement and grades tend to experience }\end{array}$ \\
Accepted & $\begin{array}{l}\text { a continuous and overall decline. online learning hurts the entire } \\
\text { academic community in madrasa. }\end{array}$ \\
\cline { 2 - 2 } Keptember 2021 & $\begin{array}{l}\text { Headmaster, Learning, Covid-19 } \\
\text { Key Word }\end{array}$ \\
\cline { 2 - 3 } How to cite & $\begin{array}{l}\text { Muhammad Fuad Zaini, Indah Melia Putri Siregar, (2021). The } \\
\text { Socialization Headmaster To Learning Covid-19 At Madrasah } \\
\text { Darussalam Foundation Gunung Tua }\end{array}$ \\
\cline { 2 - 2 } &
\end{tabular}

\section{INTRODUCTION}

In December 2019, the phenomenon of pneumonia collectively appeared on the market food northwest China Southern in Wuhan, province of Hubei, China. Commission on National Health sent the experts to Wuhan to investigate. Coronavirus is new (hereinafter referred to COVID-19 for Disease Corona Virus Disease 19) was detected in the Laboratory of Virology, Center for Control and Prevention of Diseases of China on 7th January 2020. The number of patients with viral pneumonia has skyrocketed and has spread to the whole of China, and is not inadvertently exported internationally. Coronavirus disease (Covid19) is shaking the world. Genesis great that triggered the disease spread is in the outside predictions many circles. Even among practitioners and experts in the field of crisis management. Now all sectors are affected, including the world of education, even touching the way of worship and social life (Sari, 2020). School prosecuted remain able to provide the service standard minimum to stakeholder interests are in the middle of the Work From Home (WFH) and social distancing (Ali Murfi, 2020).

World Bank says that the pandemic Covid-19 is now threatening and potentially large make the results of education is poor. Pandemic has had an 
impact big on education by closing schools almost everywhere in the world. But it is possible to cope with shocks of this and to transform the crisis into an opportunity. The step first is to successfully cope with the closure of schools, to protect health and safety, and do anything that they can to prevent students lose learning using learning distance away. At the time of the same, the countries need to start planning the opening of the back of the school. That means preventing dropping out of school, making sure the conditions of the school are healthy and using a technique new to promote the recovery of learning quickly in areas of major Be so students go back to school.

On the side of the other, Sentell, Vamos, and Orkan Okan (2020) highlights the problems specifically literacy health in crisis COVID-19, they took the opportunity is to highlight the importance of literacy health of individuals, communities, and populations, they are not only located in the " pandemic " but also an " infodemic ". Literacy health is more important than before in the face of the threat of health globally, which has an impact on the results in the entire level model of socio-ecological (SEM), including behavioral health of individuals, relationships families, behavioral organization, making of policies the country, statistics of death nationwide, and the economy international in weeks (Yudhoyono, 2020).

Their Pandemic Virus Corona has an impact on the process of education, especially in Indonesia, the Government Center to the Government of Regions issued a policy to dismiss the entire institution of education. This is done to prevent the spread of the coronavirus. On the date of 24 March 2020 the Ministry of Education and Culture of the Republic of Indonesia issued Letter Circular No. 4 the Year 2020 On Implementation of the Policy Education In Time of Emergency Deployment COVID, in a letter circular that explains that the study carried out at home by learning online / distance away are implemented to provide experience learned that means for students. The process of learning at home is more focused on education skills to live among others of the pandemic Covid-19. Minister of Education to work together with the various parties to perform learning online. Some of the parties that are focused develop the system of education online is Google Indonesia, Class Smart, Microsoft, Quipper, room teacher, Your School, and Zenius, while Kemendikbud itself also has a portal of learning itself, namely Home Learning (Sri \& Husniyatus, 2020).

To break the chain of the spread of COVID-19, various measures have been implemented by the government. Measures of prevention to covid-19 do not continue to spread with the manufacture of policies such as the establishment of several regulations in Indonesia such as imposing quarantine 
houses and restrictions on the social scale besar. 6 necessity of social distancing and quarantine themselves at home is also an impact on the world of education. The educator as manager of education requested responsiveness to carry out their duties with a way to work from home (work from home). So that the process of learning still happens. Teachers do a process of learning from home online or online until the time is and will continue in the years of learning new, namely 2020-2021.

Role as well as a Head of School / Madrasah to keep running its leadership with a well in the middle of a situation of crisis like this. Head of school/madrasah are required to apply " management crisis ", ie the process of preparing and managing situations of emergency or not unexpected that affect students, teachers, staff, and stakeholder interests. This is an important component of Public Relations (PR). This is different from the management of risk, which requires that the head of the school assess the potential threat and find how best to avoid the threat of such. In crisis management, this threat has already occurred and must be faced (Azizah et al., 2020; Zaini \& Syafaruddin, 2020).

Yayasan Darussalam Gunungtua is one of the schools that carry out the process of learning distance away is online and still take advantage of the facilities group WhatsApp in the device smartphone. Teachers give the assignment to the participant students through group Whatsapp, either through a group of people older students as well as group classes respectively. Time to learn following the schedule of eyes lessons daily. Matter of learning to learn independently and then proceed to do the task daily. However, the implementation of online learning is still not running optimally. It that because of some things that become problems in its implementation, including that due to factors of a teacher who is not proficient in technology, the problem facilities or tools of learning online are owned by the participant students, and participants students are difficult to understand the process of learning.

\section{RESEARCH METHODS}

Research is using the technique of qualitative, ie an engineering study that is conducted to collect data either through the interview, observation, and study of the case are directly spaciousness. This research was conducted at the Darussalam Gunungtua Foundation. As for analyzing the data results of the study do test confirmability, test the validity of the data, and withdrawal of conclusion (Jalaludin Rahmat, 1995; Sugiyono, 2016). 


\section{DISCUSSION}

Their Pandemic Virus Corona has an impact on the process of education, especially in Indonesia, the Government Center to the Government of Regions issued a policy to dismiss the entire institution of education. This is done to prevent the spread of the coronavirus. On the date of 24 March 2020 the Ministry of Education and Culture of the Republic of Indonesia issued Letter Circular No. 4 the Year 2020 On Implementation of the Policy Education In Time of Emergency Deployment COVID, in a letter circular that explains that the study carried out at home by learning online/distance away are implemented to provide experience learned that means for students. The process of learning at home is more focused on education skills to live among others of the pandemic Covid-19. Minister of Education to work together with the various parties to perform learning online.

In carrying out its function as an educator, the head of the madrasa must have the right strategy to improve the professionalism of the education staff in his school. Creating a climate that is conducive, giving a boost to the residents of the school, giving a boost to the whole power of education, as well as implementing a model of learning that is interesting. In the role of educator, the head of the madrassa must strive to instill, promote, and improve at least four kinds of values that is coaching the mental, moral, physical, and artistic of teachers and staff in environmental leadership.

The policy that can be carried out by the head of the madrasa is to hold online learning per government regulations that have been set. Because during the pandemic covid-19 is all learning is closed. Will but the head makes policy it is own as if the child learner is given the assignment by the teacher through via online, then the children of students that could usher in duties directly to the school in alternating order received several referrals from teachers concerned.

In the running process of learning it online also not be separated from the factors supporting and inhibiting. Problems were found to include the availability of facilities, the use of a network the Internet, the police chief of the school, and the collaboration of the parents there are factors main which were so influential in the process of learning online that is characteristic of the participant students, the characteristics of educators, the involvement of the parents and the means of pre means yan gowned use tach participant students Atar behind social economy participants learners can affect both whether or not the activities of learning distance away through the device online that is done in maximum.

The head of the madrassa as a leader or leader must provide guidance and supervision as well as the improvement of the learning online, particularly on 
the performance of teachers in the implementation of learning it online. To improve the competence of teachers head of the madrassa using force its leadership of its own. The head of the madrassa as an innovator is the head of the madrassa should be able to establish a relationship that is good between the environment, look for thinking of new, give an example, integrating every activity and create an atmosphere environment work are interesting and innovative. Motivators play an important role in improving teacher performance.

The Head of the madrasah also acts as a motivator for power education. the opinion of experts that is, the head of the madrassa as a motivator should choose a strategy that is appropriate to give motivation to the power of education in melakuk 's various tasks and functions (Fauziah, 2017). In carrying out the policy can not be separated from the strategies taken by educators in carrying out the learning process. Khaled Hamadin in the study also said that the head of the madrassa in applying the policy of Learning Online should be a lot have innovations and initiatives that can facilitate the process of learningbased e-learning. The strategy used to achieve the goal of learning is an effective and efficient strategy that is designed to have a role that is essential in the process of learning.

The strategy taken in providing the learning process is that the head of the madrasah provides direction to the teacher to inform the teaching material through the WhatsApp application. Then the teacher as a maker of material resources required to a more creative and innovative in giving the material taught to the participant students. Teachers provide materials teaching with various kinds of media such that makes video learning where the teacher explains the material through a video that, made a PowerPoint that contains the material that will be studied participants of learners, give quizzes via the app quizizz and provide test by utilizing technology google form. Besides that, in giving the task there is also require the parent-student or participant students come to school take on a task that will be done at home, then the task is returned to the school when a task has been completed done, things are done two times in one week (Dwi, 2016).

The state still deteriorated there here, both in the city and region country which has the effect that the same result of learning online that happen. Covid 19 has indeed given us a lesson to be wise in dealing with an outbreak. Not only in the Foundation Darussalam Gunungtua were experiencing difficulties in implementing the learning at the school, good schools, schools and institutions of education others should seek to carry out a variety of ways so that the transformation of knowledge to students that there are in the school can be 
channeled and can be understood. Difficulties are experienced teachers, especially teachers in teaching math as eye subjects of mathematics, physics, and chemistry experiencing difficulty teaching because of the learning that is more to squeeze the brain or mind. And they were not able to provide the material when not teach it directly. Efforts were made to provide training to teachers are online, provide stimulus in teaching also did not give the results of the maximum. Student-sisea still only suffered a setback in learning.

Achievements of student's future pandemic are also not able to be measured, even for the values of the students also had to be assisted by a teacher from the eyes of subjects respectively. The madrasa is also still waiting to see if there are any policy moves from the government so that it can minimize the situation which is getting worse day by day. Every leader of the school is very expected Sara-suggestion of from the entire activist's education, stakeholders, communities and stakeholders policy of local, provincial and central.

Not different from the policy of the government regions in Indonesia, the government district of Padang Lawas North itself is also doing the instruction of prevention to covid-19 does not spread in Paser through the efforts of the implementation of social distancing among educators, children's children, and the elderly. To realize the things that encouraged the institutions of formal education in future outbreaks of the corona to negate the activity of learning face to face directly as the days are usually included madrasas exist in the district Paser. This is intended to suppress the spread of COVID-19 which has begun to become an epidemic in Paser, East Kalimantan. Both activities learning students and working teachers can do from home as online (online). Although the activities carried out of the house will be, but the process of education still be a concern.

Amid the outbreak of corona isolating space motion teachers have to work from home to carry out the functions and duties of educating teachers is not a thing that is capable of stopping the course of education and not also as a barrier for educators to innovate. Covid-19 whose arrival has worried all walks of life in the nation and state, but on the bright side, it also presents a new tradition for teachers in giving assignments to students. A tradition that is not only new but also something rare is done when teachers and students have to communicate without being accompanied by physical presence in the classroom. Not again in the halls grade real with face-to-face direct will but through class virtual with product technology digital can transfer the information as far as a paper, anytime, and anywhere (Telaumbanua, 2020). 
The entire community of education is volatile, especially at the level of education are much lower due to change dramatically on the activities of learning and teaching are relatively new for most of the world madrasah. Teacher noise is not without reason because, in the series of implementation processes in online learning activities, it must be supported by digital knowledge and skills as the basic capital of teachers in the implementation of online learning (e-learning). Teacher professionalism in this case is encouraged to want to learn and it could be because there are still some teachers who are not used to it and are not even able to use it (Hakim, 2008). Although the teachers have to work from home, the teacher still can design teaching, managing to teach, evaluating and motivating the learning of students, also guides to form a generation of school or madrasah $d$ ith education that quality. A lot of things when it could be done with the format of learning online as by using methods synchronous, like Webex, zoom, skype, Microsoft teams, google meet, google form and others. Also asynchronous, such as learning, Whatsapp group, and others, with fixed attention to the continuation of the process of learning teaching and achievement of the quality of learning that has been planned.

Head of school/madrasah holding role important in making policies related to the management of the crisis, particularly that of education still running despite the conditions of crisis or emergency. Zainal Arifin explained that the failure of the institution of education is oftentimes caused by the quality and effectiveness of decisions and actions were taken by the head of school/madrasah. The policy (decision) of the principal of the school/madrasah should aim to give birth to benefit (goodness) to minimize crises or disasters. It is by the rules of Usul Fiqh that ' Policies imam (leader) of the people who were at the bottom of leadership should refer to the creation of man faat for the people (members). In the perspective of a more comprehensive, Connolly also explained that the priority for the security health of the global need in the activities of the leadership and coordination that builds the capacity of policy in grade macro, meso, and micro.

full responsibility in carrying out the entire process of educational activities in the school environment he leads. Head of school/madrasah are as people closest together teachers in managing the planning and in the process of learning to teach has a role which is important in terms of the increase in the professionalism of teaching. In addition to the leadership of the head of school/madrasah, neighborhood schools also participated influence on learning, namely the relationship which involves inter- personal school, the opportunity to be involved to participate in the system changes, and the 
condition of the neighborhood school that is comfortable to motivate teachers to be diligent in carrying out a task which will give effect on improving learning(Azizah et al., 2020).

\section{CONCLUSIONS}

The head of the madrassa had running roles and functions with both, namely the head of the madrassa as an educator, head of the school as a manager, head of the madrasa is an administrator, the head of the madrassa as a leader, the head of the madrassa was a supervisor, chief innovator, and the head of the madrassa was a motivator.

In the run function of his duties as the person responsible for online, the head of the madrassa joined the group Whatsapp which is managed by each teacher. Joining head madrasah with the intent to perform the control and supervision of the teachers during activities online to synchronize reporting the performance of teachers who uploaded any one time in a week. Head madrassa always build communication active and remind teachers that not only provide knowledge that nature-based curriculum course and present activities of learning that exist in the curriculum alone will however also be expected to pack the material on life skills that correspond to the context of the situation, for example, how to wash hands in order not easily exposed to viruses, how to use masks correctly, the benefits of cleaning the house, and so on.

The development of learning online is intended for teachers to increase in all directions ent learning is more effective. Learning online is an opportunity for teachers to contribute in implementing learning throughout life for the development of the skills learned are independent and capable to manage a way to learn and determine future ahead of them. Implement learning online or -line offers plenty of choice of applications that can be used during future outbreaks corona. Many applications are available from the free to the applications that need a lot of issuing costs. One of the applications that can be used is free is Google Forms.

\section{REFERENCES}

Ali Murfi. (2020). Kepemimpinan Sekolah Dalam Situasi Krisis Covid-19 Di Indonesia. Manageria: Jurnal Manajemen Pendidikan Islam, 5(1).

Azizah, N., Wijaya, C., Meutia, M., \& Zaini, M. F. (2020). Madrasah Leadership In Improving The Quality Of Students In MAN 2 Model Medan. Ta'dib: Jurnal Pendidikan Islam, 9(2), 123-134. https://doi.org/https:/ / doi.org/10.29313/tjpi.v9i2.6485

Dwi, I. (2016). Kepemimpinan Kepala Sekolah Dalam Meningkatkan Prestasi Belajar Siswa. Jurnal Inspirasi Manajemen, 4(1), 10. 
Journal of Education and Teaching Learning (JETL)

Volume 3, No 3, September 2021

Page 1-9

Fauziah, M. (2017). Peran Kepala Sekolah Dalam Meningkatkan Kinerja Guru Pada Pembelajaran Online. Jurnal Manajemen Pendidikan, 5(3), 68.

Hakim, L. (2008). Perencanaan Pembelajaran. CV. Wacana Prima.

Jalaludin Rahmat. (1995). Metode Penelitian Komunikasi Dilengkapi Contoh Analisis Statitik. Remaja Rosdakarya.

Sari, N. (2020). Problematika Pelaksanaan Pembelajaran Daringmasa Pandemic Covid19 di MIN 3 Medan. Journal Of Education And Teaching Learning (JETL), 2(3), 44-57. https:// doi.org/10.51178/jetl.v2i3.67

Sri, \& Husniyatus. (2020). Pembelajaran Online Berbasis Media Google Formulir Dalam Tanggap Work From Home Masa Pandemi Covid-19 Di Madrasah Ibtidaiyah Negeri (MIN) 1 Paser. Jurnal Pendidikan Agama Islam, 7(1), 37.

Sugiyono. (2016). Metode Penelilitian Kuantitatif, Kualitatif dan RED. Alfabeta.

Telaumbanua, D. (2020). Urgensi Pembentukan Aturan Terkait Pencegahan Covid-19 di Indonesia. QALAMUNA: Jurnal Pendidikan, Sosial, Dan Agama, 12(01), 59-70. https:// doi.org/10.37680/qalamuna.v12i01.290

Yudhoyono, A. H. (2020, May). Pendidikan Indonesia di Tengah Pandemi Covid-19. Media Indonesi. https://mediaindonesia.com/read/detail/311137-pendidikanindonesia-di-tengah-pandemi-covid-19

Zaini, M. F., \& Syafaruddin, S. (2020). The Leadership Behavior of Madrasah Principals in Improving the Quality of Education in MAN 3 Medan. Jurnal Iqra' : Kajian Ilmu Pendidikan, 5(2), 95-106. https:/ / doi.org/10.25217/ji.v5i2.649 